\title{
Improving Biomethane Production and Mass Bioconversion of Corn Stover Anaerobic Digestion by Adding NaOH Pretreatment and Trace Elements
}

\author{
ChunMei Liu, HaiRong Yuan, DeXun Zou, YanPing Liu, BaoNing Zhu, and XiuJin Li \\ College of Chemical Technology, Centre for Resource and Environmental Research, Beijing University of Chemical Technology, \\ 15 Beisanhuan East Road, Chaoyang District, Beijing 100029, China \\ Correspondence should be addressed to XiuJin Li; xjli@mail.buct.edu.cn
}

Received 2 December 2014; Revised 17 January 2015; Accepted 3 February 2015

Academic Editor: Alberto Reis

Copyright (C) 2015 ChunMei Liu et al. This is an open access article distributed under the Creative Commons Attribution License, which permits unrestricted use, distribution, and reproduction in any medium, provided the original work is properly cited.

\begin{abstract}
This research applied sodium hydroxide $(\mathrm{NaOH})$ pretreatment and trace elements to improve biomethane production when using corn stover for anaerobic digestion. Full-factor experimental tests identified the best combination of trace elements with the $\mathrm{NaOH}$ pretreatment, indicating that the best combination was with $1.0,0.4$, and $0.4 \mathrm{mg} \cdot \mathrm{L}^{-1} \cdot \mathrm{d}^{-1}$ of elements $\mathrm{Fe}$, Co, and $\mathrm{Ni}$, respectively. The cumulative biomethane production adding $\mathrm{NaOH}$ pretreatment and trace elements was $11,367 \mathrm{~mL}$; total solid bioconversion rate was $55.7 \%$, which was $41.8 \%-62.2 \%$ higher than with $\mathrm{NaOH}$-pretreatment alone and $22.2 \%-56.3 \%$ higher than with untreated corn stover. The best combination was obtained 5-9 days shorter than $\mathrm{T}_{90}$ and maintained good system operation stability. Only a fraction of the trace elements in the best combination was present in the resulting solution; more than $85 \%$ of the total amounts added were transferred into the solid fraction. Adding $0.897 \mathrm{~g}$ of $\mathrm{Fe}, 0.389 \mathrm{~g}$ of Co, and $0.349 \mathrm{~g}$ of Ni satisfied anaerobic digestion needs and enhanced biological activity at the beginning of the operation. The results showed that $\mathrm{NaOH}$ pretreatment and adding trace elements improve corn stover biodegradability and enhance biomethane production.
\end{abstract}

\section{Introduction}

Corn is one of the three major crops in China and is widely planted in the northern part of China. Corn stover is one of the most abundant lignocellulosic crop residues, with an annual production of 0.1 billion tons. Most of this residue remains unused [1]. It is quite common to see the open-field burning of corn stover across corn planting areas during the harvest season; these fires lead to serious air pollution and fire disaster and threaten traffic safety.

Biomethane production through anaerobic digestion is an energy-efficient and environmentally friendly way to treat and reuse agricultural organic materials. These wastes can be used as alternative feedstock to produce renewable energy, biomethane, valuable digested residues, liquid fertilizers, and soil conditioners [2]. However, anaerobic digestion is not currently popular, because of its poor biodegradability and digestibility. This is particularly true with treating crop residues.

Corn stover is mainly composed of polysaccharide (cellulose and hemicellulose) and lignin, forming complex threedimensional structures. The native cellulose fraction of corn stover resists enzymatic breakdown due to the complex structure of lignin and hemicellulose with the cellulose, making enzymatic disassembly difficult [3]. To obtain fast enzymatic hydrolysis of feedstock with a high sugar yield, the cell structures must be broken and porosity increased. Therefore, pretreatment is required to prepare the native cellulose fraction for enzymatic hydrolysis to monosaccharides.

Generally, pretreatment methods are classified into physical pretreatments (i.e., milling, liquid hot water, and steam), chemical pretreatments (alkaline, acidic, and oxidative), and biological pretreatments (i.e., commercial enzymes or fungi). Previous studies have found that alkali pretreatment is 
the best known method for enhancing complex material biodegradation and providing the most significant benefits [4].

In addition to pretreatment challenges, existing trace elements and nitrogen are insufficient for anaerobic microorganisms when corn stover is used alone as a feedstock for anaerobic digestion. This results in a decrease in biogas production after a certain treatment period and a process failure if no external nutrients and buffering agents are added [5]. Misunderstanding or underestimating trace nutrient requirements of methanogens can also be a serious problem in applying anaerobic biotechnology, and trace element availability as micronutrients plays a significant role in the performance and stability of substrates ranging from organic household waste to more defined lignocellulosic substrates [6].

Trace elements such as cobalt, nickel, iron, tungsten, or molybdenum serve as enzyme cofactors and are involved in the biomethane formation biochemistry [7]. Li and Dong (2001) reported that the most required trace elements were $\mathrm{Fe}, \mathrm{Co}$, and $\mathrm{Ni}$ [8]. For example, methyl-coenzyme $\mathrm{M}$ and cofactor $\mathrm{F}_{430}$ contain nickel; the acetate converting enzyme complex carbon monoxide dehydrogenase $(\mathrm{CODH})$ contains a nickel-iron-sulfur component; and the methyl- $\mathrm{H}_{4}$ SPT contains cobalt [9]. However, no information was found on the influence of trace elements on biomethane production and mass bioconversion of corn stover sole substrate.

Elemental deficiencies may negatively influence biological processes and biomethane formation; on the contrary, higher concentration of trace elements may be toxic to methanogens [10]. Consequently, adequate trace element concentrations ( $\mathrm{Fe}, \mathrm{Co}$, and $\mathrm{Ni}$ ) must be quantified accurately when added to an experimental reactor. However, essential trace element availability for the bacterial community is still a concern when studying single substrates rather than complex material mixtures, as different forms of trace elements have not been studied.

This study's objective was to determine the optimal combination of the trace elements $\mathrm{Fe}, \mathrm{Co}$, and $\mathrm{Ni}$ and to investigate the performance and synergistic effect of combining $\mathrm{NaOH}$ pretreatment with additional trace elements during corn stover anaerobic digestion. Factors evaluated included biogas production, mass bioconversion, and trace element bioavailability.

\section{Materials and Methods}

2.1. Feedstock and Inoculum. The corn stover used in this study was collected from Beichen County of Tianjin City, China. The corn stover was chopped using a paper chopper (PC500, Staida Co., Tianjin, China) and then ground through a 20 mesh screen using a universal pulverizer (YSW-180, Yanshan Zhengde Co., Beijing, China). Previous study revealed that a $\mathrm{NaOH}$ dose of $2 \%, 88 \%$ moisture content, and a $3-$ day treatment time were appropriate for wet state $\mathrm{NaOH}$ pretreatment of corn stover [1]. This method was selected because of the improvement in corn stover's biodegradability and environmental friendliness. The wet state $\mathrm{NaOH}$ pretreatment was conducted in a laboratory at ambient temperature $\left(20 \pm 2^{\circ} \mathrm{C}\right)$ for three days.
TABLE 1: Characteristics of corn stover and activated sludge used in this study.

\begin{tabular}{lcc}
\hline Indexes (dry matter) & Corn stover & Activated sludge \\
\hline Total solid (\%) & $94.93 \pm 0.36$ & $14.33 \pm 0.13$ \\
Volatile solid (\%) & $85.14 \pm 0.24$ & $5.95 \pm 0.19$ \\
Total carbon (\%) & $42.65 \pm 0.14$ & $30.12 \pm 0.39$ \\
Total nitrogen (\%) & $1.22 \pm 0.17$ & $3.28 \pm 0.32$ \\
Cellulose (\%) & $38.82 \pm 0.43$ & - \\
Hemicellulose (\%) & $29.02 \pm 0.37$ & - \\
Lignin $(\%)$ & $7.16 \pm 0.14$ & - \\
Fe $(\mathrm{mg} / \mathrm{Kg})$ & $624.59 \pm 12.85$ & $8559.60 \pm 78.43$ \\
$\mathrm{Co}(\mathrm{mg} / \mathrm{Kg})$ & $0.39 \pm 0.01$ & $3.55 \pm 0.01$ \\
$\mathrm{Ni}(\mathrm{mg} / \mathrm{Kg})$ & $7.45 \pm 0.12$ & $14.81 \pm 0.39$ \\
\hline
\end{tabular}

TABLE 2: Factors and levels of coding table.

\begin{tabular}{lcccc}
\hline & \multicolumn{4}{c}{ Level } \\
Factor & 1 & 2 & 3 & \\
& $\mathrm{mg} \cdot \mathrm{L}^{-1} \cdot \mathrm{d}^{-1}$ & $\mathrm{mg} \cdot \mathrm{L}^{-1} \cdot \mathrm{d}^{-1}$ & $\mathrm{mg} \cdot \mathrm{L}^{-1} \cdot \mathrm{d}^{-1}$ & Compounds \\
\hline $\mathrm{A}(\mathrm{Fe})$ & 1.00 & 5.00 & 10.00 & $\mathrm{FeCl}_{2} \cdot 4 \mathrm{H}_{2} \mathrm{O}$ \\
$\mathrm{B}(\mathrm{Co})$ & 0.05 & 0.20 & 0.40 & $\mathrm{CoCl}_{2} \cdot 6 \mathrm{H}_{2} \mathrm{O}$ \\
$\mathrm{C}(\mathrm{Ni})$ & 0.20 & 0.40 & 0.60 & $\mathrm{NiCl}_{2} \cdot 6 \mathrm{H}_{2} \mathrm{O}$ \\
\hline
\end{tabular}

The sludge (Inoculum) was collected from Shunyi County of Beijing City, China. Table 1 provides corn stover and sludge characteristics.

2.2. Experimental Set-Up. NaOH-pretreated corn stover was added with the three trace elements in batch anaerobic digesters, to investigate the combined effect of the trace elements and $\mathrm{NaOH}$ pretreatment on digestion performance.

Different concentrations of a well-defined trace element solution were added to anaerobic batch experiments according to our research and other authors' research [11]. To study the interaction of elements Fe $\left(\mathrm{FeCl}_{2} \cdot 4 \mathrm{H}_{2} \mathrm{O}\right)$, Co $\left(\mathrm{CoCl}_{2} \cdot 6 \mathrm{H}_{2} \mathrm{O}\right)$, and $\mathrm{Ni}\left(\mathrm{NiCl}_{2} \cdot 6 \mathrm{H}_{2} \mathrm{O}\right)$, a full-factor test was designed to find the best element combinations; Table 2 shows the coding factors and levels. Higher trace element concentrations had inhibitory and toxic effects on anaerobic digestion [12]. As such, it was necessary to determine the trace metal amounts required to supplement levels already present in the substrate and measure levels in the digester's solid and liquid residue streams to assess potential toxicity issues in their use and disposal.

Digestion experiments were performed in batch anaerobic digesters, and each experiment was repeated three times. Each digester was $1 \mathrm{~L}$ in volume, with a working volume of $0.8 \mathrm{~L}$. A loading rate of $65 \mathrm{~g} \cdot \mathrm{TS} / \mathrm{L}$ was applied for the $\mathrm{NaOH}-$ pretreated corn stover. Each digester was seeded to maintain the sludge MLSS (mixed liquid suspended solids) in the digester at $15 \mathrm{~g} / \mathrm{L}$ [13]. Urea was added to each digester to adjust the carbon-to-nitrogen ratio $(\mathrm{C} / \mathrm{N})$ to 25 , believed to be optimal for anaerobic bacteria growth. The $\mathrm{pH}$ was adjusted to $7.5 \pm 0.1$ using calcium hydroxide $\left(\mathrm{Ca}(\mathrm{OH})_{2}\right)$ solution at the beginning of the anaerobic digestion process. Prepared 
digesters were then placed in a water bath for anaerobic digestion tests. The water bath was operated at mesophilic temperature $\left(35 \pm 1^{\circ} \mathrm{C}\right)$ for a time period of 50 days.

Batch experiments were conducted for the best combination. Untreated (raw) and $\mathrm{NaOH}$-pretreated corn stover were used as separate control samples, with the same operating conditions described above.

\subsection{Analytical Methods}

2.3.1. Biogas Analyses. Each anaerobic digester's biogas production was recorded daily using the water displacement method, and the corresponding cumulative biogas volume was calculated. The measured volume was then converted to a biogas volume at a standard temperature and pressure using the ideal gas law; this volume was used to calculate biomethane volume based on the BVF (biomethane volume fraction). The biogas BVF was analyzed daily using a gas chromatograph (GC) (SP-2100, BeiFenRuiLi Co., Beijing, China) equipped with a molecular sieve (TDX-01) packed $2 \mathrm{~m} \times$ $3 \mathrm{~mm}$ stainless-steel column and a thermal conductivity detector (TCD). The temperatures of the oven, injector port, and TCD were 140,150 , and $150^{\circ} \mathrm{C}$, respectively. Argon was used as the carrier gas at a $30 \mathrm{~mL} \mathrm{~min}^{-1}$ flow rate. A standard gas (BeiFenRuiLi Co., Beijing), composed of $10.02 \% \mathrm{H}_{2}, 4.98 \%$ $\mathrm{N}_{2}, 50.1 \% \mathrm{CH}_{4}$, and $34.9 \% \mathrm{CO}_{2}$, was used to calibrate the system.

2.3.2. Chemical Composition Analyses. Total solids (TS), volatile solids (VS), and mixed liquor suspended solids (MLSS) of the corn stover, sludge, and their mixture were measured using APHA standard methods. Total carbon (TC) and total nitrogen (TN) were determined using a Vario EL/ microcube elemental analyzer (Elementar, Germany). Lignin, cellulose, and hemicellulose content were determined using an automatic fiber analyzer (ANKOM A2000i, ANKOM, USA) using procedures proposed by Van Soest [14]. The $\mathrm{pH}$ was measured with a $\mathrm{pH}$ meter (3-Star, Thermo Orion, USA). Trace elements were quantified using an inductively coupled plasma optical emission spectrometer (iCAP 7500, Thermo Scientific, USA).

2.4. Data Analyses. Each analytical datum was the mean of at least three measurements. Full-factor test results, the standard deviations, and analysis of variance were analyzed using the statistical software SPSS 17.0 for Windows; analysis of variance was tested using a least-significant difference (LSD) method.

\section{Results and Discussion}

3.1. Determination of Optimal Trace Element Level. Serial batch experiments were conducted to investigate the effect of adding trace elements on biomethane production and to determine optimal trace element levels. All corn stover samples used for trace element tests were pretreated with $\mathrm{NaOH}$. Table 3 presents biomethane productions with different concentrations of $\mathrm{Fe}, \mathrm{Co}$, and $\mathrm{Ni}$. Batch trials with the combination $\mathrm{A} 1 \mathrm{~B} 3 \mathrm{C} 2$ achieved the highest biomethane production, with concentrations of $\mathrm{Fe}, \mathrm{Co}$, and $\mathrm{Ni}$ at $1.0 \mathrm{mg} \cdot \mathrm{L}^{-1} \cdot \mathrm{d}^{-1}$, $0.4 \mathrm{mg} \cdot \mathrm{L}^{-1} \cdot \mathrm{d}^{-1}$, and $0.4 \mathrm{mg} \cdot \mathrm{L}^{-1} \cdot \mathrm{d}^{-1}$, respectively. The result is similar to findings from $\mathrm{Li}$ and Dong (2001), who reported an increase of biogas production after adding the combination of $\mathrm{Fe}\left(0.3 \mathrm{mg} \cdot \mathrm{L}^{-1} \cdot \mathrm{d}^{-1}\right)$, Co $\left(0.05 \mathrm{mg} \cdot \mathrm{L}^{-1} \cdot \mathrm{d}^{-1}\right)$, and $\mathrm{Ni}$ $\left(0.20 \mathrm{mg} \cdot \mathrm{L}^{-1} \cdot \mathrm{d}^{-1}\right)$ during anaerobic digestion [8].

Table 4 shows between-subject effects. Factor $\mathrm{B}$ and the interaction of $\mathrm{A} * \mathrm{~B} * \mathrm{C}, \mathrm{B} * \mathrm{C}, \mathrm{A} * \mathrm{C}$ were highly significant. Factors $A$ and $C$ and the interaction of $A * B$ had no effect on the test results. In terms of their respective influence, $A * B * C$ was greater than $B$, which was greater than $B * C$, which was greater than $\mathrm{A} * \mathrm{C}$. The three trace elements $\mathrm{Fe}, \mathrm{Co}$, and $\mathrm{Ni}$ interacted with one another; the interaction of all three trace elements was higher than the interaction of a single element and two elements. Speece noted that the interaction among $\mathrm{Fe}, \mathrm{Co}, \mathrm{Ni}, \mathrm{Mo}$, and Se plays an important role in anaerobic digestion processes [6]. As such, group A1B3C2 was considered to be the optimal trace element combination and was used for subsequent tests.

\subsection{Biomethane Production}

3.2.1. Daily Biogas and Biomethane Production. The daily biogas production and the biomethane volume fraction for each group were recorded throughout the digestion test period. Figure 1(a) shows the daily biogas productions for different groups, demonstrating that the overall change trends were very similar. All daily biogas productions experienced fluctuation; biogas generation started after seeding and experienced several small peaks before finally ceasing. The start-up time, the biogas production peak value, and the time of the peak value which was reached differed for different groups. The digesters with $\mathrm{A} 1 \mathrm{~B} 3 \mathrm{C} 2$ and $\mathrm{NaOH}$-pretreated corn stover experienced rapid start-up after seeding. The highest daily biogas production reached 1,525 $\mathrm{mL}$ on Day 11 for the A1B3C2 group. For the $\mathrm{NaOH}$-pretreated group, production reached $965 \mathrm{~mL}$ on Day 13; for the untreated group, production reached $880 \mathrm{~mL}$ on Day 24. Compared to the untreated corn stover and $\mathrm{NaOH}$-pretreated corn stover, results indicate that the A1B3C2 group reached higher daily biogas production within a shorter digestion time.

Figure 1(b) shows the biomethane volume fraction (BVF) of the three groups. All showed similar general trends, with the BVF first increasing and then levelling off at a relatively constant level. However, the BVFs of the A1B3C2 and $\mathrm{NaOH}-$ pretreated groups increased quickly at start-up and reached constant levels earlier. The BVF of the untreated group increased slowly and took a longer time to reach a constant level. The average $\mathrm{BVF}$ of the $\mathrm{A} 1 \mathrm{~B} 3 \mathrm{C} 2$ group was $61.8 \%$; this is higher than the BVF of $55.7 \%$ for the $\mathrm{NaOH}$-pretreated group and the BVF of $50.8 \%$ for the untreated group.

This finding indicates that combining $\mathrm{NaOH}$ pretreatment with supplemental trace elements could increase BVF. The result agrees with a study by Chen et al., who reported that the biogas volume increased by $43.4 \%$ and that BVF increased by $5.1 \%$ when $\mathrm{Fe}, \mathrm{Co}$, and $\mathrm{Ni}$ were applied at concentrations of $1.0,0.1$, and $0.2 \mathrm{mg} \cdot \mathrm{L}^{-1} \cdot \mathrm{d}^{-1}$, respectively [15]. A higher BVF may bring significant economic benefit, as 
TABLE 3: Analysis of full-factor test.

\begin{tabular}{|c|c|c|c|c|}
\hline \multirow[b]{2}{*}{ Experimental group } & \multicolumn{3}{|c|}{ Codes of factor and level (actual levels) } & \multirow[b]{2}{*}{$\begin{array}{l}\text { Cumulative biomethane } \\
\text { production }(\mathrm{mL})\end{array}$} \\
\hline & $\begin{array}{c}\mathrm{A}(\mathrm{Fe}) \\
\mathrm{mg} \cdot \mathrm{L}^{-1} \cdot \mathrm{d}^{-1}\end{array}$ & $\begin{array}{c}\mathrm{B}(\mathrm{Co}) \\
\mathrm{mg} \cdot \mathrm{L}^{-1} \cdot \mathrm{d}^{-1} \\
\end{array}$ & $\begin{array}{c}\mathrm{C}(\mathrm{Ni}) \\
\mathrm{mg} \cdot \mathrm{L}^{-1} \cdot \mathrm{d}^{-1}\end{array}$ & \\
\hline 1 & $1(1.00)$ & $1(0.05)$ & $1(0.20)$ & $10386 \pm 94$ \\
\hline 2 & $1(1.00)$ & $1(0.05)$ & $2(0.40)$ & $10001 \pm 56$ \\
\hline 3 & $1(1.00)$ & $1(0.05)$ & $3(0.60)$ & $10666 \pm 396$ \\
\hline 4 & $1(1.00)$ & $2(0.20)$ & $1(0.20)$ & $10730 \pm 62$ \\
\hline 5 & $1(1.00)$ & $2(0.20)$ & $2(0.40)$ & $10323 \pm 491$ \\
\hline 6 & $1(1.00)$ & $2(0.20)$ & $3(0.60)$ & $9638 \pm 365$ \\
\hline 7 & $1(1.00)$ & $3(0.40)$ & $1(0.20)$ & $10320 \pm 118$ \\
\hline 8 & $1(1.00)$ & $3(0.40)$ & $2(0.40)$ & $11367 \pm 361$ \\
\hline 9 & $1(1.00)$ & $3(0.40)$ & $3(0.60)$ & $11132 \pm 163$ \\
\hline 10 & $2(5.00)$ & $1(0.05)$ & $1(0.20)$ & $9593 \pm 274$ \\
\hline 11 & $2(5.00)$ & $1(0.05)$ & $2(0.40)$ & $10517 \pm 141$ \\
\hline 12 & $2(5.00)$ & $1(0.05)$ & $3(0.60)$ & $10839 \pm 239$ \\
\hline 13 & $2(5.00)$ & $2(0.20)$ & $1(0.20)$ & $10322 \pm 456$ \\
\hline 14 & $2(5.00)$ & $2(0.20)$ & $2(0.40)$ & $9868 \pm 259$ \\
\hline 15 & $2(5.00)$ & $2(0.20)$ & $3(0.60)$ & $10076 \pm 388$ \\
\hline 16 & $2(5.00)$ & $3(0.40)$ & $1(0.20)$ & $10307 \pm 101$ \\
\hline 17 & $2(5.00)$ & $3(0.40)$ & $2(0.40)$ & $10158 \pm 560$ \\
\hline 18 & $2(5.00)$ & $3(0.40)$ & $3(0.60)$ & $10861 \pm 76$ \\
\hline 19 & $3(10.00)$ & $1(0.05)$ & $1(0.05)$ & $10274 \pm 367$ \\
\hline 20 & $3(10.00)$ & $1(0.05)$ & $2(0.40)$ & $10504 \pm 649$ \\
\hline 21 & $3(10.00)$ & $1(0.05)$ & $3(0.20)$ & $10340 \pm 103$ \\
\hline 22 & $3(10.00)$ & $2(0.20)$ & $1(0.05)$ & $10127 \pm 441$ \\
\hline 23 & $3(10.00)$ & $2(0.20)$ & $2(0.40)$ & $10678 \pm 582$ \\
\hline 24 & $3(10.00)$ & $2(0.20)$ & $3(0.20)$ & $10116 \pm 33$ \\
\hline 25 & $3(10.00)$ & $3(0.40)$ & $1(0.05)$ & $10872 \pm 156$ \\
\hline 26 & $3(10.00)$ & $3(0.40)$ & $2(0.40)$ & $10767 \pm 372$ \\
\hline 27 & $3(10.00)$ & $3(0.40)$ & $3(0.20)$ & $9837 \pm 105$ \\
\hline
\end{tabular}

TABLE 4: The result of between-subjects effects (dependent variables: $X$ ).

\begin{tabular}{|c|c|c|c|c|c|}
\hline Source & III model 0 & $\mathrm{df}$ & Mean square & $F$ & Sig. \\
\hline Correcting model & $42544349.6^{\mathrm{a}}$ & 26 & 1636321.137 & 2.635 & 0.001 \\
\hline Intercept & 22460617248 & 1 & 22460617248 & 36165.606 & 0.000 \\
\hline A & 933550.222 & 2 & 466775.111 & 0.752 & 0.476 \\
\hline B & 6618446.889 & 2 & 3309223.444 & 5.328 & 0.008 \\
\hline C & 644693.556 & 2 & 322346.778 & 0.519 & 0.598 \\
\hline $\mathrm{A} * \mathrm{~B}$ & 2944740.444 & 4 & 736185.111 & 1.185 & 0.328 \\
\hline $\mathrm{A} * \mathrm{C}$ & 6475833.778 & 4 & 1618958.444 & 2.607 & 0.046 \\
\hline $\mathrm{B} * \mathrm{C}$ & 8525127.111 & 4 & 2131281.778 & 3.432 & 0.014 \\
\hline $\mathrm{A} * \mathrm{~B} * \mathrm{C}$ & 16401957.556 & 8 & 2050244.694 & 3.301 & 0.004 \\
\hline Error & 33536652.000 & 54 & 621049.111 & & \\
\hline Total & 22536698250.000 & 81 & & & \\
\hline Total correction & 76081001.556 & 80 & & & \\
\hline
\end{tabular}

${ }^{\mathrm{a}} R^{2}=0.559$ (regulate $R^{2}=0.347$ ). 


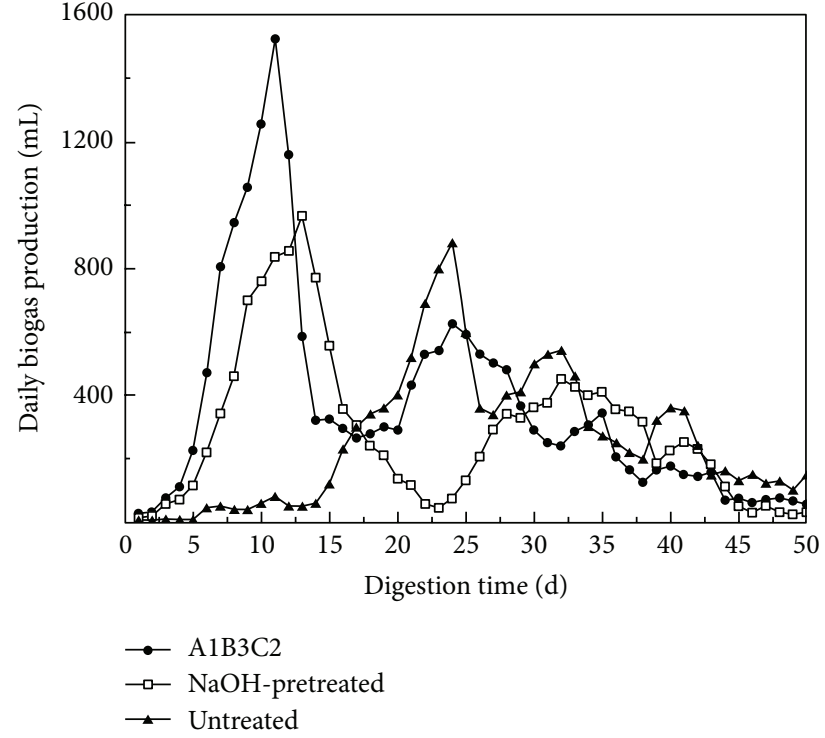

(a)

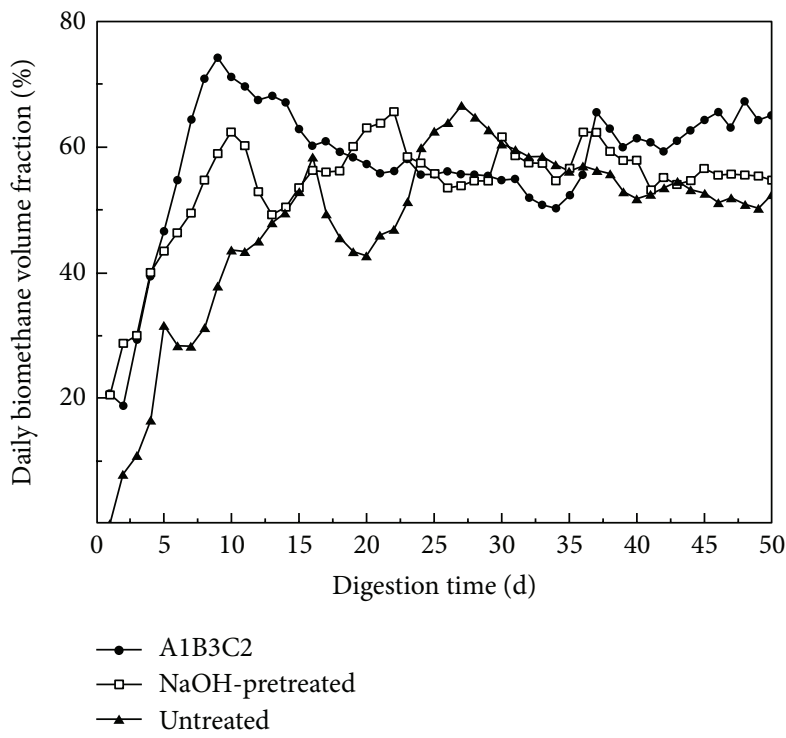

(b)

FiguRE 1: The daily biogas production (a) and biomethane volume fraction (b) for different groups.

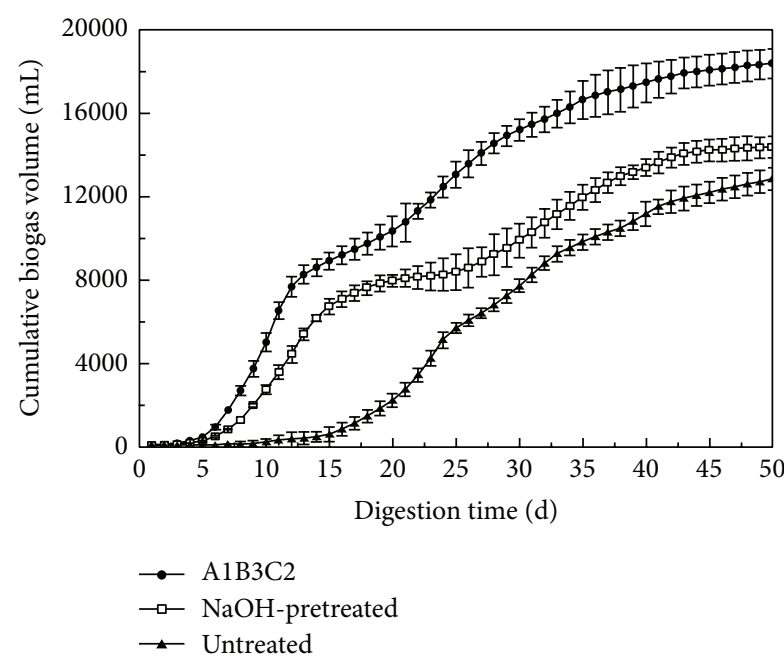

(a)

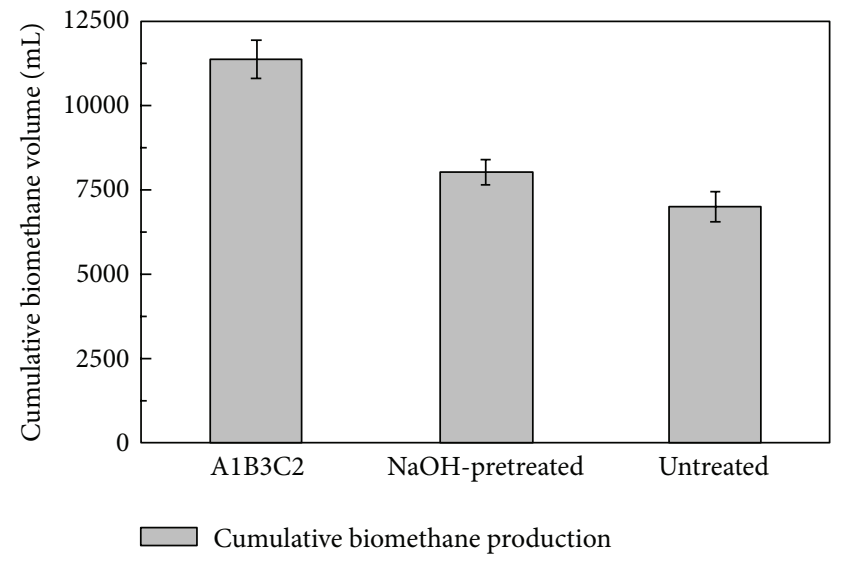

(b)

FIGURE 2: Cumulative biogas production (a) and biomethane production (b) for different groups.

it increases the biomethane yield for a given amount of corn stover.

\subsubsection{Cumulative Biogas and Biomethane Production. Cumu-} lative biogas production was calculated based on the daily biogas production during anaerobic fermentation. Figure 2(a) shows the changes in cumulative biogas productions for the three groups studied. After 50 days of digestion, the $\mathrm{A} 1 \mathrm{~B} 3 \mathrm{C} 2$ group reached the highest cumulative biogas production of $18,400 \mathrm{~mL}$. This was $27.9 \%$ higher than tests with $\mathrm{NaOH}$-pretreatment and $43.1 \%$ higher than tests with untreated corn stover. This increase was attributed to the synergistic effect from $\mathrm{NaOH}$ pretreatment and trace elements addition. The synergistic effect was mainly due to the complementary characteristics of digested corn stover, more balanced nutrients, and improved biodegradability.

Multiple comparisons using the LSD method were performed on the cumulative biogas productions for the three groups. Test results showed that the cumulative biogas production with the $\mathrm{A} 1 \mathrm{~B} 3 \mathrm{C} 2$ group was significantly higher than those of the others $(a=0.05)$. It further confirmed that combining $\mathrm{NaOH}$ pretreatment with trace elements could significantly improve biogas production when corn stover was used as a sole feedstock.

The energy contained in biogas is determined using both biogas volume and BVF. Cumulative biomethane volume, 
TABLE 5: Biogas and biomethane yields and bioconversion rates for different groups.

\begin{tabular}{|c|c|c|c|c|c|c|}
\hline \multirow{2}{*}{ Groups } & \multicolumn{2}{|c|}{ Biogas yields } & \multicolumn{2}{|c|}{ Biomethane yields } & \multicolumn{2}{|c|}{ Bioconversion rates (\%) } \\
\hline & $\mathrm{mL} / \mathrm{g} \mathrm{TS}$ & $\mathrm{mL} / \mathrm{g} \mathrm{VS}$ & $\mathrm{mL} / \mathrm{g} \mathrm{TS}$ & $\mathrm{mL} / \mathrm{g}$ VS & TS & VS \\
\hline A1B3C2 & $354 \pm 17$ & $393 \pm 31$ & $219 \pm 12$ & $243 \pm 24$ & $55.7 \pm 0.5 \%$ & $65.9 \pm 0.6 \%$ \\
\hline $\mathrm{NaOH}$-pretreated & $277 \pm 23$ & $307 \pm 26$ & $154 \pm 16$ & $171 \pm 20$ & $45.6 \pm 0.2 \%$ & $57.8 \pm 0.5 \%$ \\
\hline Untreated & $247 \pm 15$ & $275 \pm 18$ & $135 \pm 14$ & $150 \pm 19$ & $35.6 \pm 0.9 \%$ & $53.0 \pm 0.3 \%$ \\
\hline
\end{tabular}

representing total energy gain, was calculated by timing daily biogas production with the corresponding BVF. Figure 2(b) shows the results. When anaerobic fermentation processes were completed, the cumulative biomethane volume reached $11,367 \mathrm{~mL}, 8,018 \mathrm{~mL}$, and 7,009 $\mathrm{mL}$ for the A1B3C2, $\mathrm{NaOH}-$ pretreated, and untreated corn stover groups, respectively. The A1B3C2 group's cumulative biomethane volume was $41.8 \%$ higher than the $\mathrm{NaOH}$-pretreated group and $62.2 \%$ higher than the untreated corn stover group, respectively. This confirms the significant influence of trace elements and $\mathrm{NaOH}$ pretreatment on biomethane production. Multiple comparisons using the LSD method also showed a significant difference $(a=0.05)$ in cumulative biomethane volume among three groups. Speece also demonstrated that adding trace elements of $\mathrm{Fe}, \mathrm{Co}$, and Ni could significantly increase biomethane production [16].

3.2.3. Digestion Time $T_{90}$. Digestion time is another indicator of substrate biodegradability and digestion efficiency. Digestion time $\mathrm{T}_{90}$ was defined as the number of days required to achieve $90 \%$ of potential biogas generation.

This study's anaerobic digestion process was extended for up to 50 days past the time when biogas production was near zero. The $\mathrm{T}_{90}$ for the A1B3C2 group was 33 days, 5-9 days shorter than $\mathrm{NaOH}$-pretreated and untreated groups. The significant reduction in digestion time further indicated that the A1B3C2 group not only initiated digestion quickly, but also accelerated the biogas production process. GonzalezGil et al. [17] studies indicated that adding $\mathrm{Ni}$ and Co can shorten the reaction's lag phase and facilitate the methanogen process [17]. This could bring significant economic benefits, by increasing the production efficiency or treatment capacity of a digester by using a shortened digestion time.

\subsection{Mass Bioconversion}

3.3.1. Bioconversion of TS and VS. Biogas is generated from a substrate's biological conversion during anaerobic digestion. Organic matter conversion into biogas reduces the amount of organic dry matter, resulting in a decrease in TS and VS.

Based on mass balance, the TS and VS bioconversion rates were calculated; Table 5 shows the results. Both TS and VS were reduced significantly through anaerobic microorganism bioconversion. However, the TS and VS bioconversion rates differed from each other and also differed between the three groups. The TS bioconversion rate was lower than VS for all three groups. TS and VS bioconversion rates for the A1B3C2 group were $55.7 \%$ (TS) and $65.9 \%$ (VS). These rates were $22.2 \%-56.3 \%$ higher than with the $\mathrm{NaOH}$-pretreated group

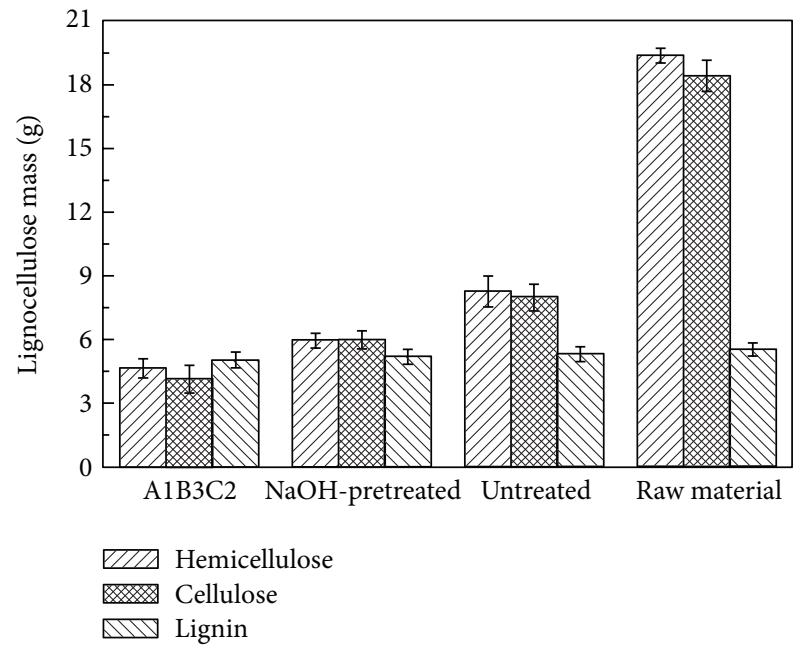

FIgURE 3: The changes of chemical compositions.

and $14.0 \%-53.1 \%$ higher than with the untreated corn stover. The A1B3C2 group achieved a higher bioconversion rate, representing significant biodegradability improvement. This is attributed to the combined role of $\mathrm{NaOH}$ pretreatment and trace elements, which improved corn stover biodegradability and also provided more balanced nutrients for anaerobic bacteria.

3.3.2. Bioconversion of Chemical Compositions. LCH (lignin, cellulose, and hemicellulose) are the main components of corn stover, accounting for $75.0 \%$ of the total dry matter and providing the main carbon sources for anaerobic microorganisms. Biogas production is greatly affected by the availability and digestibility of cellulose and hemicellulose and the association of lignin with the carbohydrates. The more biogas produced, the more the components are reduced. In this part of the study, cellulose, hemicellulose, and lignin bioconversion rates were analyzed to investigate main component bioconversion characteristics.

Figure 3 shows the changes in chemical compositions for the three studied groups at the end of anaerobic digestion. Bioconversion rates of the cellulose, hemicellulose, and lignin differed across the three groups. Hemicellulose and cellulose were clearly converted for all three groups. The total $\mathrm{LCH}$ bioconversion rates were $72.8 \%, 65.1 \%$, and $54.9 \%$ for the $\mathrm{A} 1 \mathrm{~B} 3 \mathrm{C} 2, \mathrm{NaOH}$-pretreated, and untreated groups, respectively, when compared to raw material. The bioconversion rates of hemicellulose significantly increased by $76.1 \%, 69.3 \%$, and $57.5 \%$ for the $\mathrm{A} 1 \mathrm{~B} 3 \mathrm{C} 2, \mathrm{NaOH}$-pretreated, and untreated 
TABLE 6: The amount of trace elements in feedstock and effluent.

\begin{tabular}{|c|c|c|c|c|c|}
\hline \multirow{2}{*}{ Element } & \multicolumn{3}{|c|}{ Feedstock (mg) } & \multicolumn{2}{|c|}{ Effluent (mg) } \\
\hline & Activated sludge & Corn stover & Element addition & Liquid & Solid \\
\hline $\mathrm{Fe}$ & $122.16 \pm 0.23$ & $32.47 \pm 0.85$ & 48.00 & $12.66 \pm 0.21$ & $192.18 \pm 1.42$ \\
\hline Co & $0.19 \pm 0.01$ & $0.07 \pm 0.01$ & 19.47 & $0.78 \pm 0.01$ & $19.20 \pm 0.12$ \\
\hline $\mathrm{Ni}$ & $0.21 \pm 0.01$ & $0.39 \pm 0.02$ & 19.20 & $1.70 \pm 0.13$ & $17.38 \pm 0.16$ \\
\hline
\end{tabular}

TABLE 7: System stability of anaerobic digestion.

\begin{tabular}{lcccc}
\hline Different groups & $\mathrm{pH}$ & Ammonia nitrogen $(\mathrm{mg} / \mathrm{L})$ & Alkalinity $(\mathrm{mg} / \mathrm{L})$ & Volatile fatty acids $(\mathrm{mg} / \mathrm{L})$ \\
\hline A1B3C2 & $7.44 \pm 0.02$ & $490 \pm 30$ & $8550 \pm 850$ & $269 \pm 50$ \\
NaOH-pretreated & $7.45 \pm 0.02$ & $518 \pm 56$ & $10700 \pm 300$ & $511 \pm 10$ \\
Untreated & $7.47 \pm 0.02$ & $490 \pm 42$ & $9255 \pm 225$ & $785 \pm 21$ \\
\hline
\end{tabular}

groups, respectively. The bioconversion rates of cellulose significantly increased by $77.5 \%, 67.5 \%$, and $56.7 \%$ for the $\mathrm{A} 1 \mathrm{~B} 3 \mathrm{C} 2, \mathrm{NaOH}$-pretreated, and untreated groups, respectively. Lignin amounts had almost no change. The A1B3C2 group achieved the maximum $\mathrm{LCH}$ bioconversion rate.

Pretreatment before anaerobic digestion is a simple and effective method to improve lignocellulosic material biodegradability. Pretreatment can decompose cellulose and hemicellulose into relatively biodegradable components and break the link between polysaccharide and lignin to make cellulose and hemicellulose more accessible to bacteria [18]. Additionally, adding trace elements for corn stover anaerobic digestion can enhance microorganism activity. This result further verified $\mathrm{NaOH}$ pretreatment effectiveness and the ability of trace elements to improve biodegradability and enhance bioenergy production.

3.3.3. Trace Element Bioavailability. Methanogens absorbed and fixed trace elements through extracellular complexion, extracellular precipitation, and intracellular accumulation [19]. Fe, Co, and Ni concentrations in effluent were measured to assess trace element availability at the end of anaerobic digestion. Table 6 lists the trace elements present in the feedstock and effluent from the A1B3C2 group. The table shows that effluent trace elements mainly existed as solids in the A1B3C2 group; the amounts of trace elements in the solids accounted for $93.8 \%, 96.1 \%$, and $91.1 \%$ of total Fe, Co, and $\mathrm{Ni}$ amounts added, respectively. Karlsson et al. (2012) also noted that only a fraction of trace elements is present in solution; in most cases, trace element bioavailability for anaerobic bacteria metabolic pathways is not related to the total amount in the medium [11]. The calculated result shows that approximately $89.6 \% \mathrm{Fe}, 97.2 \% \mathrm{Co}$, and $87.4 \% \mathrm{Ni}$ of the total amount added were converted to solid form. As such, adding Fe $0.897 \mathrm{~g}$, Co $0.389 \mathrm{~g}$, and Ni $0.349 \mathrm{~g}$ at the beginning of operation can both satisfy anaerobic digestion needs and enhance biological activity.

3.4. System Stability. It is important that a digester operate in a stable state, while maintaining good performance. When using corn stover as a sole substrate, the digestion system has an increased potential for instability, due to possible lower buffering capability. Digestion system stability depends on a number of factors, including $\mathrm{pH}$, volatile fatty acids (VFAs), ammonia nitrogen, and alkalinity. This study assessed these parameters to evaluate the stability of corn stover anaerobic digestion when combining $\mathrm{NaOH}$ pretreatment and trace element supplements.

Table 7 shows that each group's $\mathrm{pH}$ value was maintained at 7.30-7.45 at the end of methanogenesis throughout the digestion period. Ammonia nitrogen and alkalinity were important parameters in maintaining anaerobic system stability. Free ammonia was produced from organic nitrogen degradation, causing alkalinity variation in the anaerobic system. Adequate ammonia content can effectively improve the efficiency of anaerobic digestion, while ammonia nitrogen may inhibit methanogen activity when levels exceed $2,000 \mathrm{mg} / \mathrm{L}$. Table 7 shows that the ammonia nitrogen for the three groups ranged from 490 to $518 \mathrm{mg} / \mathrm{L}$, within an acceptable range. The anaerobic digestion system alkalinity was $8,550-10,700 \mathrm{mg} / \mathrm{L}$. This higher alkalinity supports strong system stability. These findings indicate that the corn stover with $\mathrm{NaOH}$ pretreatment and trace element supplements did not inhibit ammonia nitrogen, while maintaining high alkalinity, thereby ensuring stable system operation.

VFAs were important intermediate products during anaerobic digestion. VFAs in the A1B3C2 group were significantly lower than those with $\mathrm{NaOH}$ pretreatment and untreated group (Table 6). The A1B3C2 group benefited methanogenic bacterial growth and biomethane production.

\section{Conclusions}

Combining $\mathrm{NaOH}$ pretreatment and trace element addition is an effective method to improve corn stover biodegradability and enhance biomethane production. The best combination was adding $1.0,0.4$, and $0.4 \mathrm{mg} \cdot \mathrm{L}^{-1} \cdot \mathrm{d}^{-1}$ of trace elements $\mathrm{Fe}, \mathrm{Co}$, and $\mathrm{Ni}$ (A1B3C2), respectively. When compared to $\mathrm{NaOH}$-pretreated and untreated corn stover, A1B3C2 group experienced $41.8 \%$ and $62.2 \%$ more cumulative biomethane 
volumes, $22.2 \%-56.3 \%$ and $14.0 \%-53.1 \%$ more TS and VS bioconversion rates, and 5-9 days shorter $\mathrm{T}_{90}$, while also maintaining good operational stability.

\section{Conflict of Interests}

The authors declare that there is no conflict of interests regarding the publication of this paper.

\section{Acknowledgments}

The authors are grateful to the fund supports from the University Doctorial Foundation (20120010110004) and the Twelfth Five-Year National Key Technologies R\&D Program (no. 2010BAC67B03).

\section{References}

[1] M. Zheng, X. Li, L. Li, X. Yang, and Y. He, "Enhancing anaerobic biogasification of corn stover through wet state $\mathrm{NaOH}$ pretreatment," Bioresource Technology, vol. 100, no. 21, pp. 51405145, 2009.

[2] H. Pobeheim, B. Munk, J. Johansson, and G. M. Guebitz, "Influence of trace elements on methane formation from a synthetic model substrate for maize silage," Bioresource Technology, vol. 101, no. 2, pp. 836-839, 2010.

[3] K.-L. Chang, J. Thitikorn-Amorn, J.-F. Hsieh et al., "Enhanced enzymatic conversion with freeze pretreatment of rice straw," Biomass \& Bioenergy, vol. 35, no. 1, pp. 90-95, 2011.

[4] P. Salehian, K. Karimi, H. Zilouei, and A. Jeihanipour, "Improvement of biogas production from pine wood by alkali pretreatment," Fuel, vol. 106, pp. 484-489, 2013.

[5] L. Hinken, I. Urban, E. Haun, I. Urban, D. Weichgrebe, and K.H. Rosenwinkel, "The valuation of malnutrition in the monodigestion of maize silage by anaerobic batch tests," Water Science and Technology, vol. 58, no. 7, pp. 1453-1459, 2008.

[6] R. E. Speece, Nutrient Requirements in Anaerobic Digestion of Biogas, USA Elsevier Applied Sciences Publication, London, UK, 1987.

[7] K. Mori, M. Hatsu, R. Kimura, and K. Takamizawa, "Effect of heavy metals on the growth of a methanogen in pure culture and coculture with a sulfate-reducing bacterium," Journal of Bioscience and Bioengineering, vol. 90, no. 3, pp. 260-265, 2000.

[8] Y. X. Li and C. J. Dong, "Determining trace metals stimulating methanogens and their supplement dosage," Environmental Pollution \& Control, vol. 23, no. 3, pp. 116-118, 2001.

[9] H. C. Friedmann, A. Klein, and R. K. Thauer, "Structure and function of the nickel porphinoid, coenzyme $\mathrm{F}_{430}$, and of its enzyme, methyl coenzyme M reductase," FEMS Microbiology Reviews, vol. 87, no. 3-4, pp. 339-348, 1990.

[10] S. Jansen, G. Gonzalez-Gil, and H. P. van Leeuwen, "The impact of $\mathrm{Co}$ and Ni speciation on methanogenesis in sulfidic mediaBiouptake versus metal dissolution," Enzyme and Microbial Technology, vol. 40, no. 4, pp. 823-830, 2007.

[11] A. Karlsson, P. Einarsson, A. Schnürer, C. Sundberg, J. Ejlertsson, and B. H. Svensson, "Impact of trace element addition on degradation efficiency of volatile fatty acids, oleic acid and phenyl acetate and on microbial populations in a biogas digester," Journal of Bioscience and Bioengineering, vol. 114, no. 4, pp. 446-452, 2012.
[12] Y. Y. Li and B. Li, "The anaerobic digestion of and the requirements for trace elements of coal gasification wastewater," Journal of Wuyi University, vol. 4, no. 22, pp. 1-5, 2008.

[13] R. H. Zhang and Z. Q. Zhang, "Biogasification of rice straw with an anaerobic-phased solids digester system," Bioresource Technology, vol. 68, no. 3, pp. 235-245, 1999.

[14] P. J. van Soest, J. B. Robertson, and B. A. Lewis, "Methods for dietary fiber, neutral detergent fiber, and nonstarch polysaccharides in relation to animal nutrition," Journal of Dairy Science, vol. 74, no. 10, pp. 3583-3597, 1991.

[15] C. M. Chen, G. M. Zeng, B. B. Zhang et al., "Study on improvement of trace activators and energy production in Anaerobic digestion of municipal organic refuse," Journal of Nanhua University, vol. 18, no. 1, pp. 12-16, 2004.

[16] R. E. Speece, "Anaerobic biotechnology for industrial wastewater treatment," Environmental Science \& Technology, vol. 17, no. 9, pp. 416-427, 1983.

[17] G. Gonzalez-Gil, R. Kleerebezem, and G. Lettinga, "Effects of nickel and cobalt on kinetics of methanol conversion by methanogenic sludge as assessed by on-line $\mathrm{CH}_{4}$ monitoring," Applied and Environmental Microbiology, vol. 65, no. 4, pp. 1789-1793, 1999.

[18] H. Chen, L. Liu, X. Yang, and Z. Li, "New process of maize stalk amination treatment by steam explosion," Biomass \& Bioenergy, vol. 28, no. 4, pp. 411-417, 2005.

[19] D. Q. Zhou, Microbiology Tutorials, Beijing Higher Education Press, Beijing, China, 2002. 

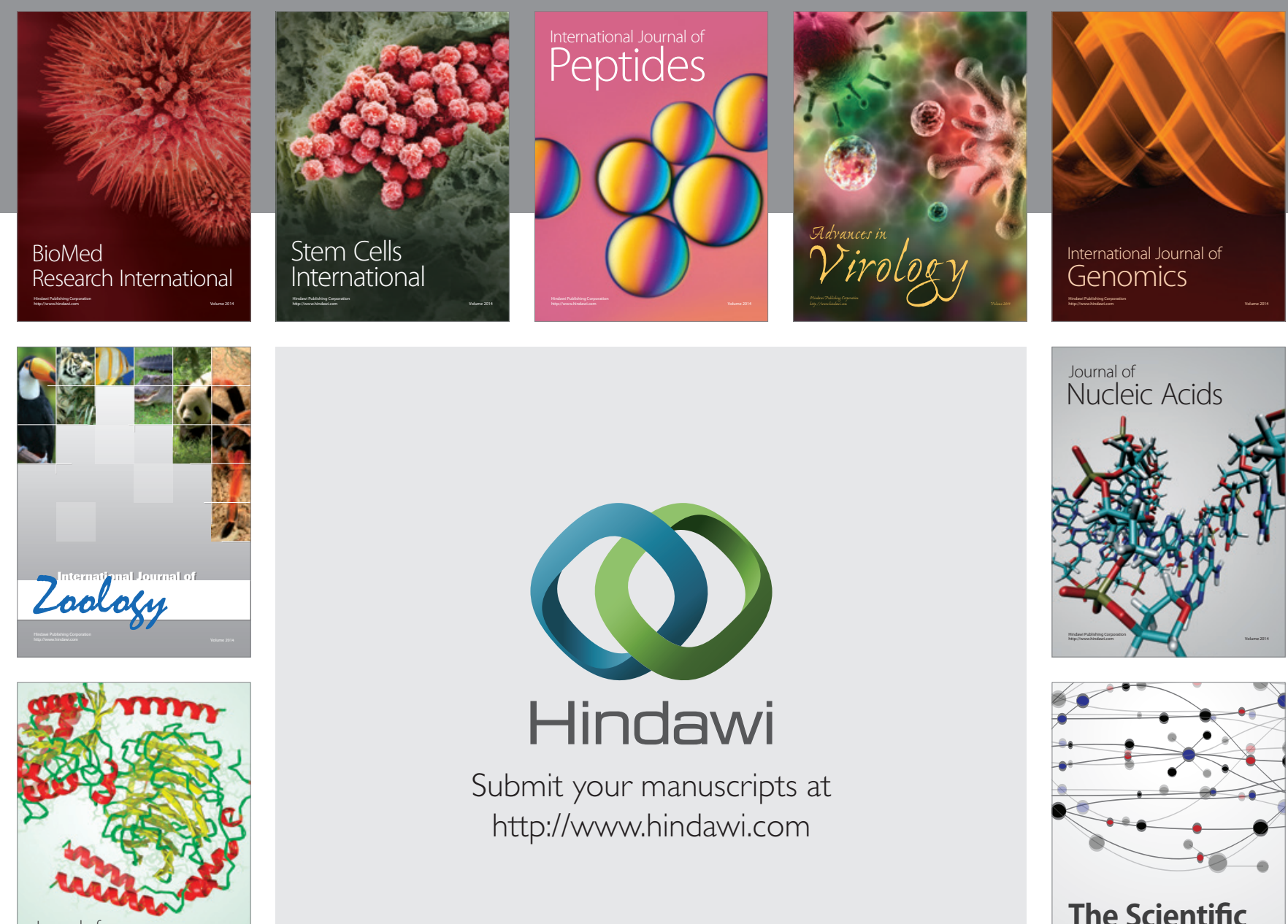

Submit your manuscripts at

http://www.hindawi.com

Journal of
Signal Transduction
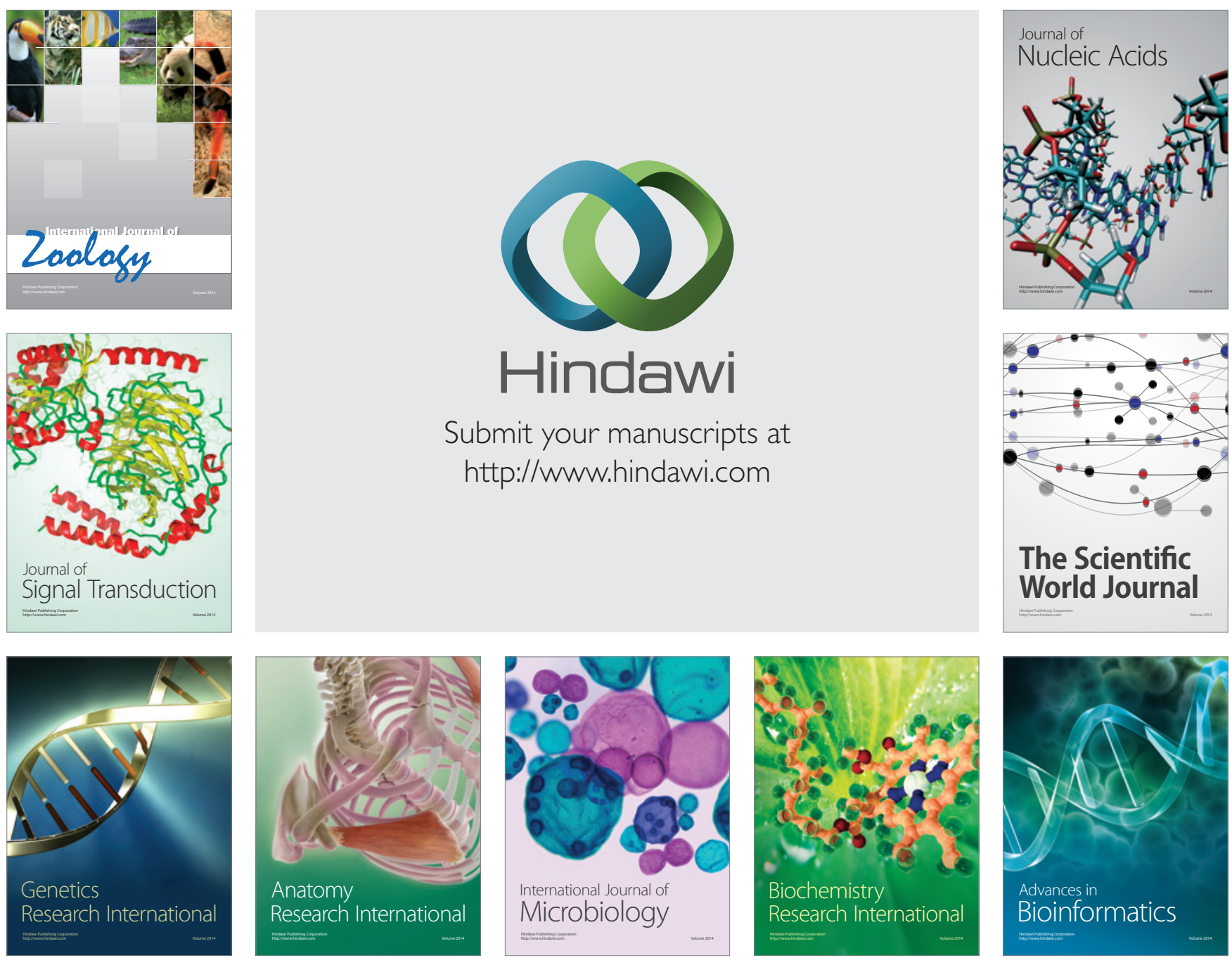

The Scientific World Journal
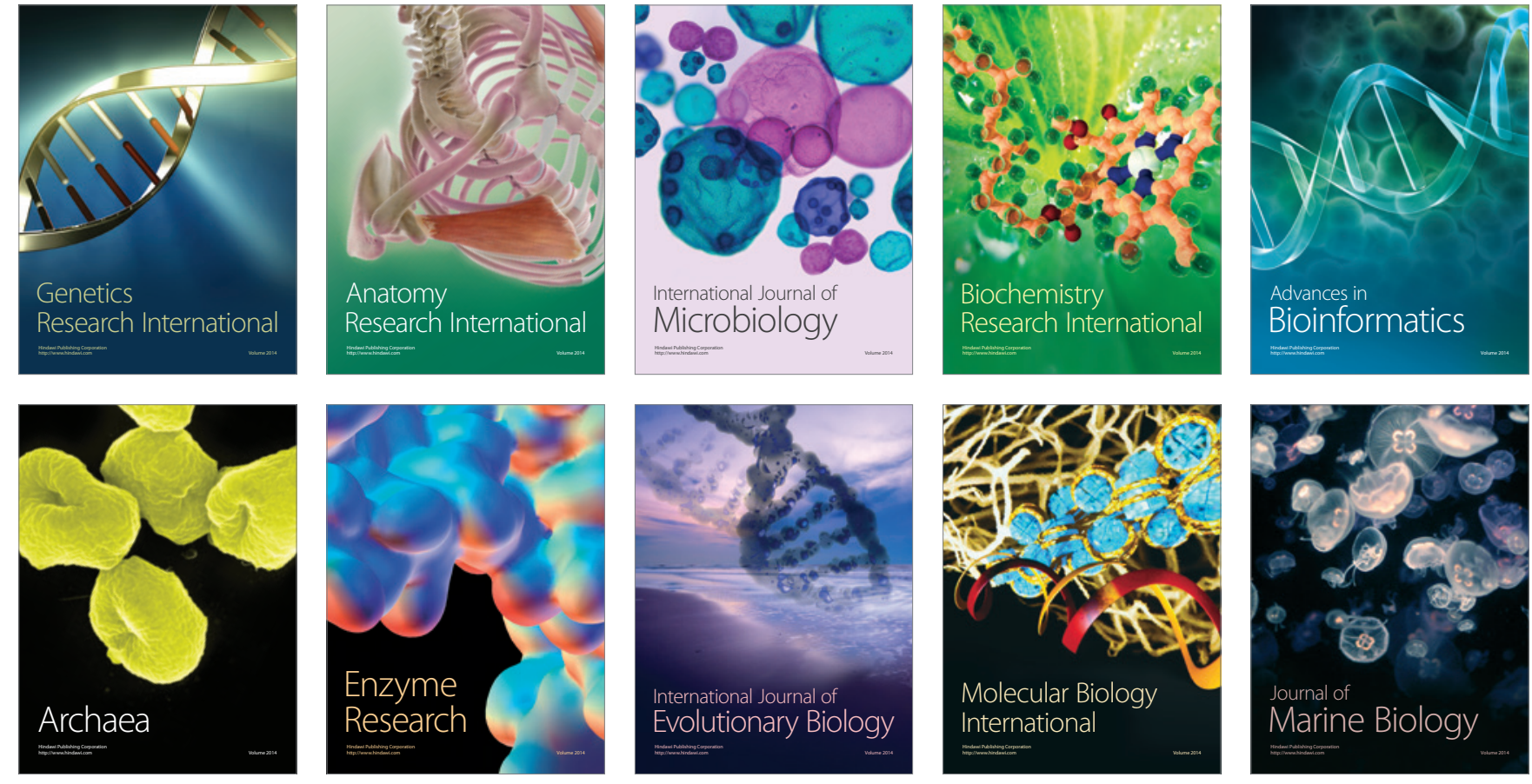